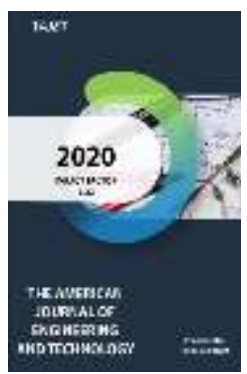

Journal Website: http://usajournalshub.c om/index,php/tajet

Copyright: Original content from this work may be used under the terms of the creative commons attributes 4.0 licence.

\section{Analysis Of Road Accidents Involving Children}

Ikromov Ikboljon Abdukhalilovich

Senior Lecturer, Department Of Land Transport Systems And Their Exploitation, Fergana Polytechnic Institute, Uzbekistan

Akhunov Javlon Abdujalilovich Assistant, Department Of Land Transport Systems And Their Exploitation, Fergana Polytechnic Institute, Uzbekistan

\title{
ABSTRACT
}

The article presents the analysis of statistical data of drilling road accidents with children. Proposals are given for the development of new technologies for the prevention of injuries to children in road traffic accidents, as well as training them in road safety rules and ensuring the safety of pedestrians on the roads around educational institutions.

\section{KEYWORDS}

Automobile, road, pedestrian, speed and road traffic accidents, road safety rules.

\section{INTRODUCTION}

Road traffic accidents and their consequences cause serious damage to the economy of our country and the spiritual life of society. The large number of children injured in road accidents requires increased attention to their safety.
The results of the study show that there is a problem for children, especially given the psychophysiological development of modern traffic requirements in cities. The risk of trafficking in persons in children than in adults is mainly related to their psychological characteristics [1,2,3]. 
According to the World Health Organization's 2018 Road Safety Report, 1.35 million people worldwide die each year from road traffic crashes. In particular, according to the report, road traffic injuries are the leading cause of death for children and young people aged 5-29. Between 20 and 50 million people suffer from non-fatal injuries, most of which result in disabilities.

\section{MATERIALS AND METHODS}

The main objective of the study should be to develop new technologies to prevent injury to children in road traffic accidents, as well as educate them on road safety and pedestrian safety on the roads around educational institutions. One of the most pressing problems today is to improve the efficiency of work on the prevention of road traffic accidents, conduct research to prevent road traffic accidents involving vehicles and pedestrians, including children.

According to statistics, for 11 months of 2018, 1275 road accidents involving children occurred on the territory of the Republic of Uzbekistan, as a result of which 1121 children were injured and 204 children died. In the first 11 months of 2019, there were 1,143 road accidents involving children, as a result of which 1,001 people were injured and 170 died. In 2019, 131 road traffic accidents involving children were registered on the roads of the Tashkent region. As a result of these incidents, 21 children were killed and 110 injured. In addition to the above data, we will analyze road traffic accidents involving children in the Fergana region in 2014-2018. (Figures 1, 2)[4,5,6].

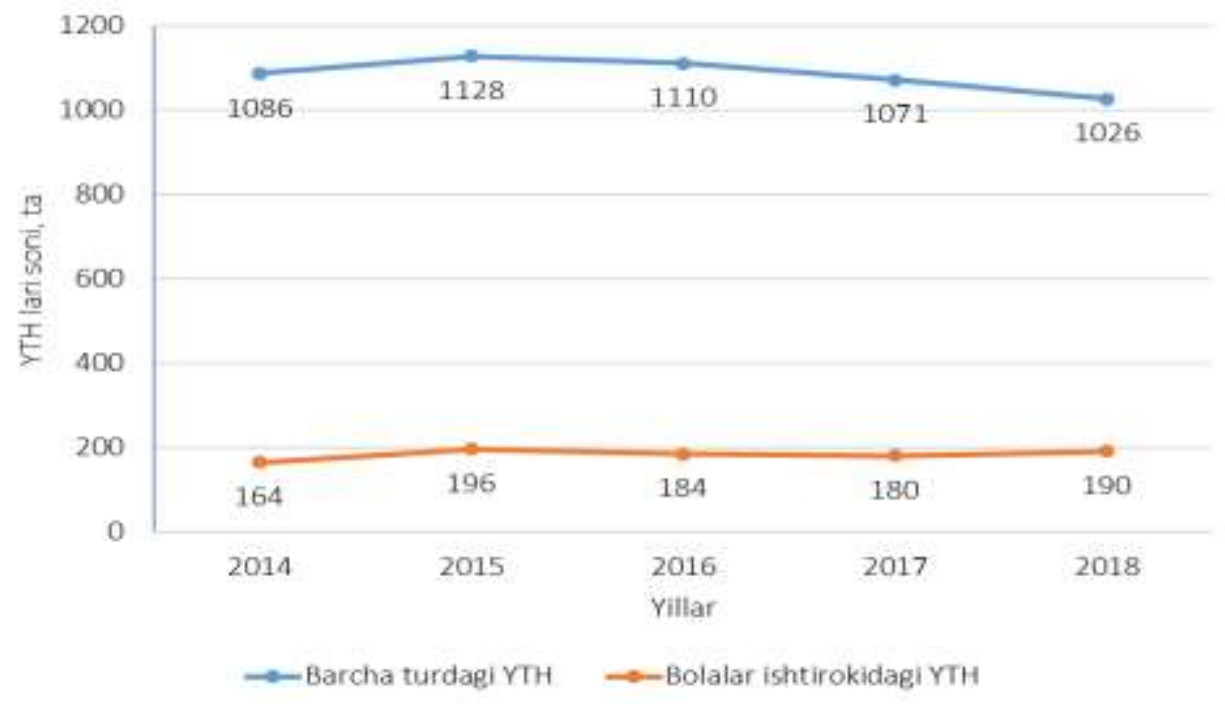

Figure 1. Distribution by years of road traffic accidents involving children in Fergana region.

Let's analyze the graph in the first figure. In 2014, the number of road traffic accidents involving children was 164, but by 2018 this figure had grown to 190.
The numbers on the graph show that over the past 5 years, the number of road accidents involving children has increased by $13.68 \%$. 


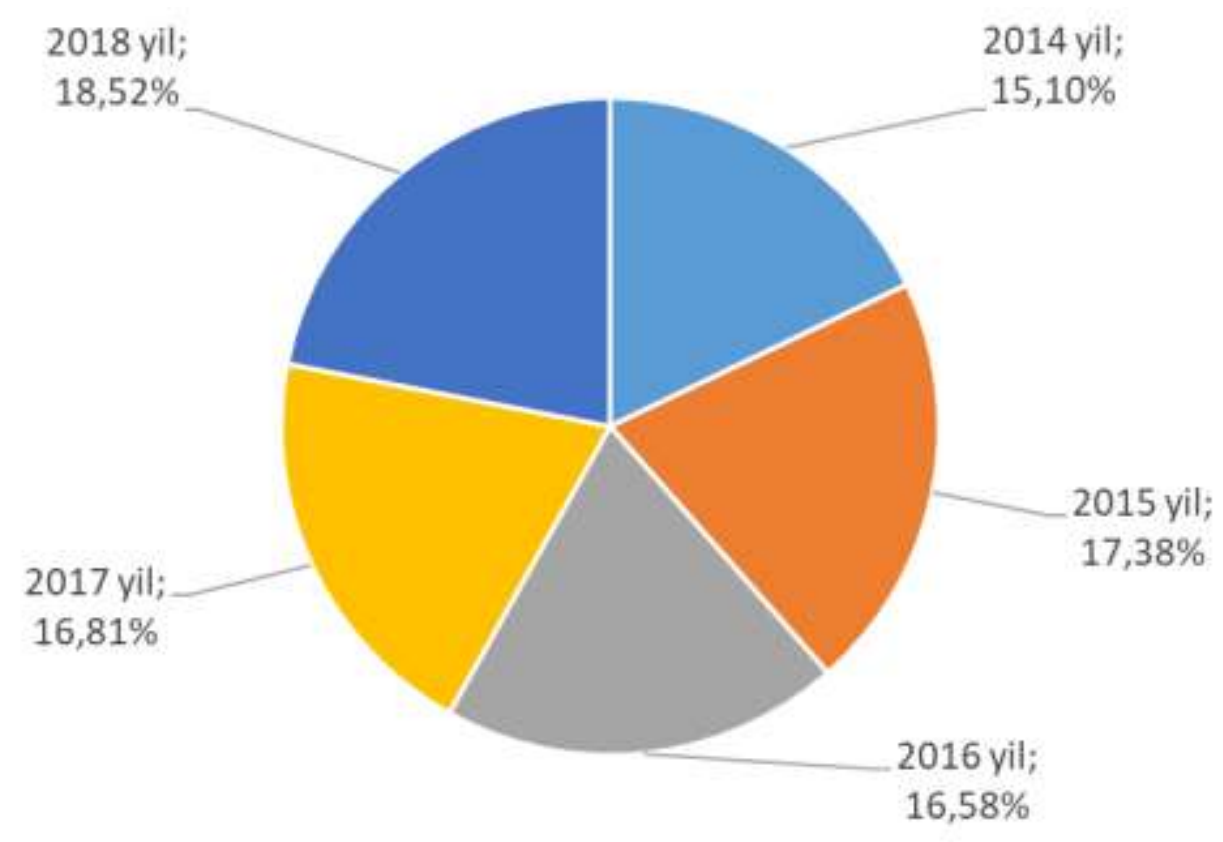

Figure 2. Percentage of road traffic accidents involving children in Fergana region by year.

Let's analyze the second picture. $15.10 \%$ of the total number of road accidents in 2014 were children who were involved in road accidents. By 2018, we see that this figure was $18.52 \%$. The figures show that the number of road accidents involving children is increasing from year to year.

\section{CONCLUSION}

In short, the prevention of road accidents involving children remains an urgent problem throughout the world, including in our republic. To solve this problem, a lot of scientific research is needed. The increasing density of urban transport makes roads the most dangerous area for children, and, accordingly, the prevention of injuries in child traffic accidents remains the most pressing issue in our time.

\section{REFERENCES}

1. https://ddu110grodno.schools.by/pages/psih ologija-detej-i-bezopasnost-dorozhnogodvizhenija
2. Жахон соғлиқни сақлаш ташкилотининг 2018 йилда йўл харакати хавфсизлиги буйича глобал хисобот.

3. https://yhxbb.uz

4. https://kun.uz/

5. Abdukhalilovich, I. I., \& Obloyorovich, M. H. (2020). Support for vehicle maintenance. Asian Journal of Multidimensional Research (AJMR), 9(6), 165-171.

6. Hayitov, O. G., Umirzoqov, A. A., Iskandarov, J. R., \& Suvanov, F. R. (2020). Prospects for the industrial use of coal in the world and its process of reproducing. Novateur Publication's JOURNALNX-A Multidisciplinary Peer Reviewed Journal, 6(5), 240-247. 